\title{
Up Close and Personal: Feeling the Past at Urban Archaeological Sites
}

TRACY IRELAND

$\mathrm{M}$ arkers of memory and identity are increasingly manifested in urban landscapes in forms both literal and material. In cities with settler colonial origins, archaeology has become a frequent means by which these markers are produced. Archaeological remains conserved in situ - frozen in an urban 'time slice'- embed genealogies and narratives of origins in the layered fabric of the city.

Archaeological excavation, followed by the conservation in situ of the excavated remains (that is preserving them in the place where they were found), is a process of making a particular past visible, while the associated processes of urban design, display techniques and technologies, and particular interpretative strategies, work towards providing for different kinds of engagements with these archaeological traces. ' Comparing the 'Big Dig' archaeological site conserved in situ in Sydney, Australia, with the Pointe-à-Callière Musée d'archéologie et 
d'histoire in Montreal, Canada, I explore how the affective, aesthetic qualities of these ruins produce emotions and embodied experiences that are interpreted as sustaining identity and cultural memory. Using Sara Ahmed's concept of 'affective economies', I want to understand what is distinctive about this particular form of social/emotional/material entanglement, and explore what these ruins 'do' in the context of the city and how they appear to create stable objects of memory and identity from a much more contingent and complex matrix of politics, social structures, and the more-than-human materiality of the city.

\section{THE BIG DIG SITE}

First, let's take a walk through the historic district of the Rocks on Sydney Harbour. Tourists and locals come here to enjoy its distinctive urban landscape of modest Georgian buildings, narrow lanes and steep staircases cutting between streets quarried into the sandstone promontory that today anchors the Harbour Bridge. The Cumberland and Gloucester Street excavation site is up high above the waterfront, close to the arched approaches to the Bridge. It is also known as the Big Dig Education Centre, as the remains were incorporated into a youth hostel and education facility in an innovative design by Tzannes Architects. The site was first excavated in the 1990s by Godden Mackay Logan Heritage Consultants (GML), working with historian Grace Karskens, who together produced a number of important publications about the site and also advised on its conservation and interpretation. ${ }^{3}$

The conserved site opened to the public in 2009-2010, and it is possible for visitors to wander amongst the ruins and remains, to walk on the flagstones of an early laneway, to cross worn thresholds and enter the foundations of small-roomed houses built by convicts and their families in the first few decades of colonial settlement. The stone building remains intersect with, and in places incorporate or modify, the tilted sedimentary layers of the natural, sandstone bedrock, outcrops of which gave this district its name of 'The Rocks'."

The early 2000s saw a sharp rise in the number of displays based on archaeological remains conserved in situ in Sydney. A few colonial sites had been conserved earlier, particularly in the Rocks as well as the remains of the first Government House, built in 1788, which were excavated in the 1980s and incorporated into the Museum of Sydney, which opened in 1995. However, the increase in displays clustered in the historic centre of Sydney, and in Parramatta, the second colonial settlement, suggested that between the 1980s - when historical archaeological excavations began to regularly occur prior to 


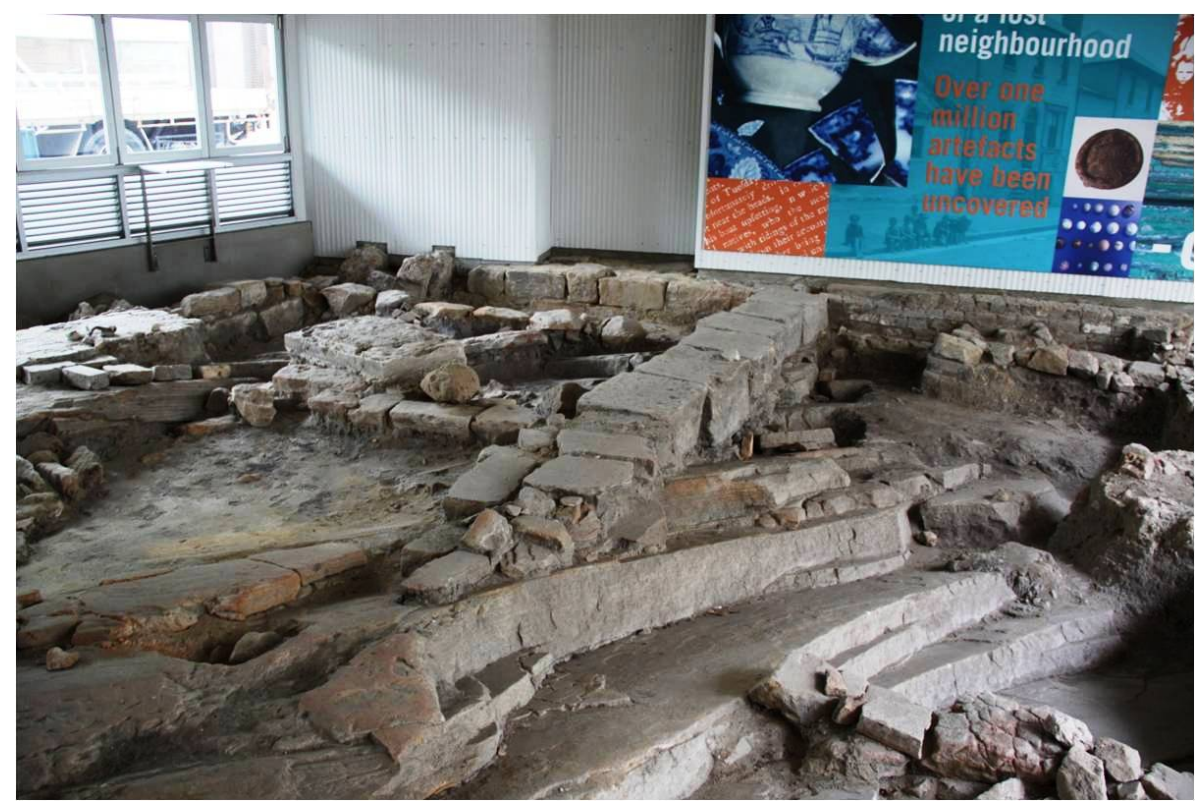

The Big Dig archaeological site, within the Sydney Harbour Youth Hostel, July 2014 (Photograph Tracy Ireland)

development - and the first decade of the twenty-first century, significant changes had occurred in the perceived value and meaning of these archaeological sites over this period.

I have explored some of the political and cultural contexts for these changes in earlier publications, along with the results of a survey that explored visitor experiences and opinions. ${ }^{5}$ This research was aimed at thinking more deeply about the process and outcomes of conservation in situ, approached largely from the archaeological heritage management perspective. However, my experience of taking student groups to these sites, and observing the impact that different types of archaeological displays had, inspired me to ask further questions about what is distinctive in the way these archaeological remains of the colonial, settler past evoke emotional responses that produce experiences or feelings that are articulated as pertinent to identity and to shared cultural memory.

The experience of physical intimacy with material relics from the past was a feature of many of the responses to my survey and this echoed community-based research by Sian Jones in the United Kingdom on how people experience the 'authenticity' of heritage objects. ${ }^{.}$She argued that a particularly intense and contagious experience of 'authenticity' results when people have physical access to heritage objects, and how the traditional processes of heritage conservation, which often dictate the closing off of access and opportunities for 
touching old materials, may in fact diminish how the authenticity or cultural value of conserved items might be perceived and experienced by individuals and communities. Attempting to further unpack Jones' description of the experience of authenticity as a 'numinous quality' or an 'enchantment' of materials objects, Cornelius Holtorf argued that authenticity is perceived through qualities of 'pastness', which are experienced 'as a consequence of perceptible material clues indicating wear and tear, decay, and disintegration, among other factors'.? Importantly, he comments on the fact that, to be legible as 'pastness', these material and visual clues must conform in some way to contemporary stereotypes, or preconceived notions about the past.

I want to come back to these ideas about the web or network of relationships between people and objects, embodied experiences of materiality and place, and an aesthetic code for 'pastness'. But first I will turn to Sara Ahmed's concept of 'affective economies' as a helpful framework for approaching these questions about what archaeological remains and ruins ' $\mathrm{do}^{\prime}$, and what this means for how social experiences of memory and identity are produced through heritage places and things.

\section{ECONOMIES OF AFFECT}

Sara Ahmed is prominent among scholars from a range of disciplines who are concerned with the role of emotions in different forms of social and political attachment, interrogating the role of feelings in how individuals make sense of their place in the world, where they belong to, and who they belong with.s Ahmed describes affect as what 'sticks', or what sustains the connection between ideas, values and objects, challenging the notion that emotions and feelings are only private things. She has been concerned to understand how emotions travel between bodies, how they are produced by material and social worlds of discourse and politics and how they connect or align individuals with communities' and 'bodily space with social space'.. Arguing that 'affective economies' need to be seen as social and material, as well as psychic, she suggests that 'the accumulation of affective value shapes the surfaces of bodies and worlds'. ${ }^{10}$ However, Ahmed's aim is not so much to understand or identify these emotions as if universal and purely embodied or originating within the body, but to understand the political and economic stuctures that produce these effects, thus exposing the social norms that these emotional responses invest in. She argues that 'feelings appear in objects, or indeed as objects with a life of their own, only by the concealment of how they are shaped by histories, including 
histories of production - labor and labor time - as well as circulation and exchange'."

I suggest Ahmed describes here an important aspect of how heritage acts as a material structure for the accumulation of affect around identity, belonging and attachment, and thus how the emotional experience of authenticity and other material qualities works to conceal (at least to some extent) the social, political and economic history of the production of this effect. For ruins and archaeological remains, deep histories are in place that make some materials and places particularly 'sticky' with affect - the worn stone threshold, the broken fragment of a china doll, crumbling masonry. They evoke what John Ruskin termed a 'mysterious sympathy' which both Sian Jones and Cornelius Holtorf have interpreted as a visual, material code for authenticity, a code that reproduces notions about what the past should look and feel like. ${ }^{2}$

\section{COLONIAL RUINS}

I next want to consider the relevance to this discussion, and to this notion of a visual code for authenticity that works to accumulate affect, with the power and persistence of the language of desire that surrounds ruins and archaeological remains in the western cultural imaginary, which received its expression in eighteenth century and later Romanticism..$^{13}$ In the twenty-first century we are seeing a renewed interest in the legacy of Romanticism - an interest in exploring feelings, aesthetic responses and against the over-rationalisation of scientific approaches. Such an approach seems very appropriate to the study of cultural heritage and of how and why people form attachments to places and the narratives that surround them. Sara Ahmed's agenda, however, carefully distinguishes itself from an interest in the Romantic. Her aim is not to return to, or reinvigorate, the Romantic tradition, but rather to counter it by clearly pointing out that she does not see emotions as a pathway to an alternative source of truth. For Ahmen, 'emotions are effects rather than origins'. ${ }^{\text {"t }}$

The Romantic view of ruins centred on how they linked temporality and materiality, place and history and the power of this convocation to alter the perception of the witnessing subject. However, contemporary ruin discourses, Andreas Huyssen and Kevin Hetherington both claim, depart from the Romantic confidence in progress and are more obsessed with the past 'as a source of refuge in uncertain times'. ${ }^{15}$ In a related vein, Anne Laura Stoler's notion of 'imperial debris' also seeks to carefully avoid the melancholic gaze of colonial nostalgia. She seeks to use the 
power of ruins to 'condense alternative senses of history' in order to expose the longevity of structures of colonial dominance. ${ }^{16}$

I suggest that the Romantic concept of the sensuous, individual subject remains central to contemporary ruin discourse and to related cultural discourses of archaeology and heritage, as work by Hamilakis and Handler, which I discuss below, also attests. But the legacy of Romantic thought in both archaeology and heritage has been deliberately de-emphasised in the settler societies of Australia and Canada, where the empirical objectivity of the archaeological record, or the 'archaeological resource' as it was often termed, was strategically emphasised as part of the professionalization of these domains in the twentieth century.

Bruce Trigger's History of Archaeological Thought stressed the dichotomy between universalism and romanticism in the development of modern archaeology. He claims that both nationalism and postmodernism grew out of romanticism and idealism, and that their coming together in the field of archaeology produced an unresolved tension at the heart of the discipline. ${ }^{1{ }^{1}}$ However, Yannis Hamilakis' more recent study of archaeology and Hellenic nationalism argues persuasively that the entanglement of archaeology and so-called 'modern' forms of nationalism and heritage must recognise that these cultural forms have not evolved in a linear succession, but as 'hybrids, re-formulations and modifications', encompassing enduring pre-modern forms of understanding. He concludes emphatically that in Greece, modern 'archaeology has not constituted a radical break from previous experiential encounters with the material past'. ${ }^{\text {ts }}$

The colonial, archaeological remains that I explore here clearly do not resemble the monumental ruins of ancient temples found by colonial explorers. But the ways in which they are experienced, and the emotional responses they produce, are nevertheless shaped by both a 'modernist' understanding of their scientific archaeological value - that is, how they have been produced by the scientific process of archaeological excavation and how they embody the research potential of archaeological evidence, as well as by the trope of the sensuous materiality of ruins, recognised through their visual traits of authenticity. The Romantics described ruins in terms of their ability to create a space for individual contemplation, for desire and longing. The desire for heritage, for experiences of memory and identity, can be equated with what Richard Handler has described as the 'desire for authenticity' and his concept of 'possessive individualism', where individuals seek to sustain not only their sense of their individual essence but also their sense of belonging to a cultural collectivity through possession of 
authentic culture. ${ }^{19}$ 'Ruin memory' thus remains significant in understanding the aesthetic effects and affective intensity of these sites, as well as their interpretation as sustenance for identity and belonging, despite the modernist, scientistic practices of heritage conservation and archaeological heritage management that shaped their excavation and preservation.

\section{Pointe-À-Callière, Montreal Museum of Archaeology and History}

I now turn to my second example of colonial archaeological remains conserved in situ, in Montreal in the francophone province of Quebec in Canada. As in the Rocks in Sydney, the colonial past is palpable and inescapable in Quebec. Heritage and cultural tourism were two key contexts studied by anthropologist Richard Handler in his influential ethnographic study of Quebecois nationalism published in 1988. ${ }^{20}$ The Pointe-à-Callière Musée d'archéologie et d'histoire opened in 1992. This year marked the 350" anniversary of the founding of Montreal, and just as we saw in Sydney in the years before 1988 - the bicentenary of colonial settlement - heritage projects intensified in Quebec in the lead up to this significant commemoration. This followed decades of fraught cultural politics culminating in the narrowly defeated 1995 independence referendum. ${ }^{21}$

Pointe-à-Caillière is essentially presented as an origin site for Montreal, making visible the origins of francophone 'civilisation' in North America, just as the first acts of British colonisation in Australia are made manifest at the Museum of Sydney.2. Interest in the archaeology of colonial settlement in Quebec developed only from the 1970s. It has been outlined by Pierre Desrosiers, with a particular focus on the emergence of forms of in situ conservation and other museological approaches deriving from, he suggests, the 'living history museum' approach developed by Artur Hazelius in Sweden in 1891, an approach later used at Colonial Williamsburg in Virginia in the USA..$^{23}$ Desrosiers points out that by the late 1990s more than 60 per cent of 476 'museological institutions' or heritage sites in Quebec presented historical interpretations 'in the places where that history took place'; that is, on archaeological sites. ${ }^{24}$

This focus on preserving archaeological sites in situ - for which Quebec has an international reputation - echoes Norah's description of lieux de memoire, emphasising the territoriality of colonial history as a basis for sovereignty and cultural uniqueness. ${ }^{25}$ Desrosiers suggests that this situation causes a tension, or 'rupture', in the heritage management of these sites, between more meaningful archaeological research that 


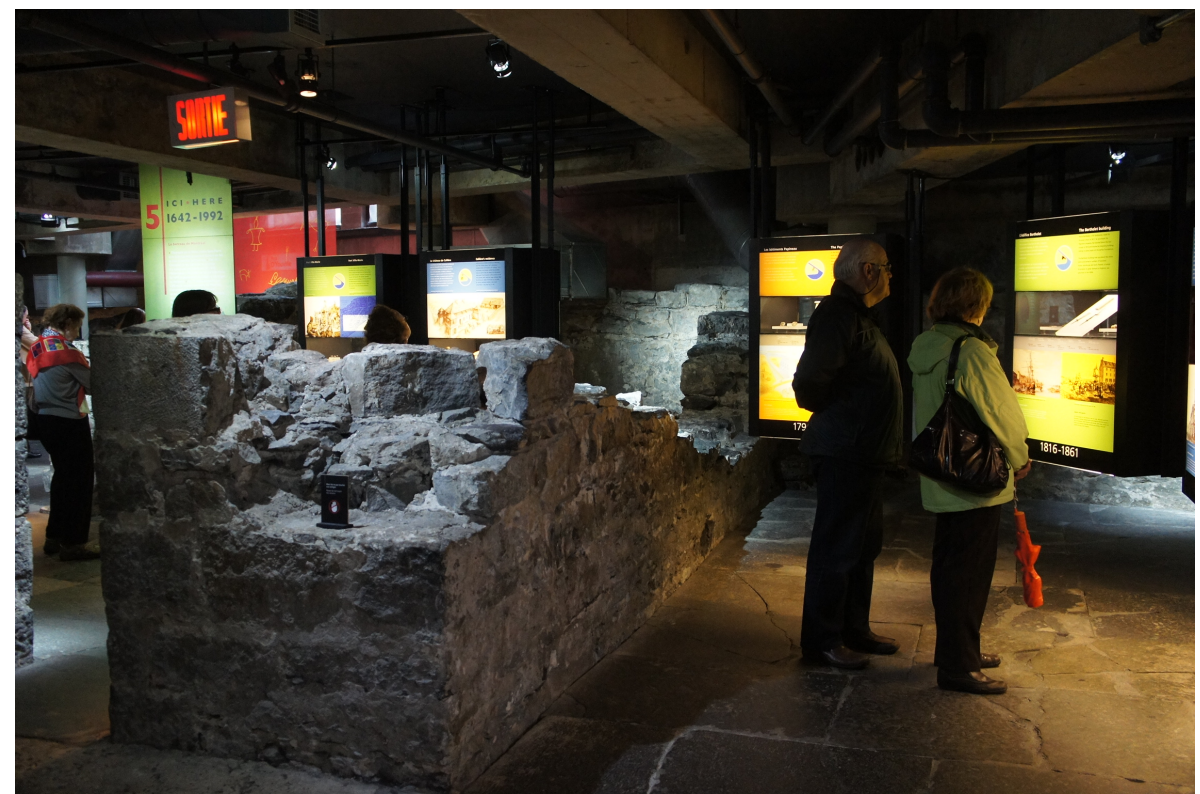

Pointe-à-Callière Musée d'archéologie et d'histoire, Museum of Archaeology and History in Montreal, September 2012 (Photograph Tracy Ireland)

would contextualise the archaeological collections, and the work that is demanded to service the day to day demands of the interpretative and exhibition programs that these sites must continually refresh and update. However, Desrosiers also proposes that archaeologists in Quebec have 'little interest' in questions of epistemology and theory, and that historical archaeology has concerned itself largely with questions of methodology, and around urban development and regional settlement..$^{20}$

Pointe-à-Caillière has been carefully shaped to present a 'diachronic' presentation of multiple periods from the past, directly inspired by the crypt of Notre Dame de Paris, which also displays material from the many different periods of past construction that lie beneath the pavement around the cathedral. ${ }^{27}$ Pointe-à-Callière is a more formal site museum than my Sydney example. It is presented as the 'birthplace of Montreal, but with a distinctive authenticity achieved by the way in which the site has been conserved and presented in a subterranean crypt where visitors can mingle closely with, and even touch, ruins and surfaces from different periods from Montreal's past. It is this form of presentation that led me to a comparison of Pointe-à-Callière and the Big Dig site in Sydney, rather than what might seem to be its more likely counterpart as an 'origin site', The Museum of Sydney on the site of the first Government House. 
The archaeological remains displayed at the Museum of Sydney are both remotely behind glass, and also focused solely on the house, although the Museum has a broader historical and cultural scope. The displays at Pointe-à-Callière focus more closely on a sense of place, including the lost natural environment, than the Big Dig site in Sydney. Its houses and yards, along with its rich artefact displays, evoke individuals and families and a past neighbourhood or community. While individuals are conjured through interpretative techniques at Pointe-àCaillière, it more straightforwardly presents the origins of French colonialism in North America, and closely details the complex evolution of the urban fabric of Montreal. The darkened archaeological crypt enhances the tactile and visual qualities of the stone, earth and timber remains and visitors walk on surviving stone flags from demolished, earlier buildings. Contrasting with the aged patina of the in situ materials, digital screens display reconstructions of what has been lost, and the fragility and rarity of what has been preserved.

\section{THE Dialectics OF THE CITY}

'humans make cities, but not exactly as they please' ${ }^{\prime 28}$

Finally, I bring us back to a consideration of how memory and place are entangled in the urban context. In a straightforward way, Pointe-àCallière is a monument to the origins of francophone civilisation in North America. But at another level it can be read as a loving homage to the city of Montreal. Discussing memory and the city, anthropologist Michael Herzfeld has compared the 'stratigraphic richness of the truly organic city', to the ossified, over-conserved historic site. Herzfeld suggests that while Rome remains a vibrant organic city, he cites Athens and Bangkok as examples of cities which have alienated their past through over-conservation and planning. It seems that Herzfeld, too, pines for the Romantic, neglected ruin outside social control, to experience authenticity in the city..$^{20}$ On the other hand, archaeologist Laurent Olivier claims that for archaeology to be possible at all, there needs to be that moment of 'otherness', a recognition of difference between the present and the past, and that this sense of alienation again replicates a Romantic approach to modernity..$^{30}$

It is clear that in the settler context this process of alienation has indeed been fundamental to the creation of the archaeological sites I am considering here. I have briefly referred to the rise of historical archaeology (as the archaeology of the colonial period) from the 1970s in 
both Sydney and Montreal. This process materially consolidated the haphazard evidence of European colonial expansion into an industrious founding of nations and national cultures. Thus archaeology has been a technique via which the progress and modernity of Montreal and Sydney is illustrated in their deep urban layers, contrasting the steel and concrete of today, with modest, fragile, colonial origins.

The conservation in situ of these archaeological remains contributes to the perceived richness of the layered urban fabric of Sydney and Montreal. But they are also quite separate from it due to the technologies of material conservation that are deployed to stabilise the archaeological fabric in a form created by both a scientific/stratigraphic reading of it as archaeological evidence, as well as an aesthetic rendering based on a visual code of authenticity, that demands perceptible clues to the passage of time. Shannon Lee Dawdy has recently given a compelling account of how archaeology, as a means of analysing materiality, might add a missing dimension to urban studies by focusing on the instability of the 'archaeological time slice' and by viewing it dialectically - not as a stable materialisation of a moment of history, but as a 'vibrant' illustration of 'the dialogue between the past and the present, and the tense feedback loop between human intention and material agency' ${ }^{3 .}$

These conserved archaeological sites present a paradox. They attempt to stabilise and materialise a particular memory of the city. However, conservation has artfully and intentionally created these ruins. And yet these materials are not stable and wholly within human control. They remain embedded in the more-than-human earthen matrix of the city substrate, subject to unexpected eruptions of ground water, salt attack and biological growths - an object lesson in the vibrancy of matter and of forces outside culture and human intention. ${ }^{2}$

\section{CONCLUSIONS: MEMORY OBJECTS}

'Qu'est-ce qui reste quand on a tout oublié? L'objet...' ${ }^{33}$

In their excellent overview of memory and place Carole Blair, Greg Dickinson and Brian L. Ott put forward a number of propositions as generally accepted in memory studies: that memory takes place in groups; is activated by present concerns; that it narrates shared identities and concepts of belonging; and relies on material and/or symbolic supports. ${ }^{3}$ In exploring these two sites of archaeological conservation in situ as materialities of memory and identity, I have been concerned to understand more deeply how they work in social, emotional and material terms. As many commentators have observed, memory is 
organised and ordered by place, and place is experienced through the body and the senses, as well as through discourse and politics. ${ }^{35}$ This encounter with archaeological remains can be seen as a social behaviour that allows both an experience of identity and memory, or an encounter with the past as, and of, 'the other'.

Michael Herzfeld has critiqued the 'discovery' of memory by archaeologists, suggesting they have been too quick to replace previous concepts, such as cultural 'influence' or 'structures', with 'memory', in an attempt to 'democratise' their interpretations of the past and move away from 'top down deterministic structuralist approaches', towards something that is felt to be more personal and individual ${ }^{36}$ However, he suggests that this approach tends to reproduce uncritical assumptions about 'belonging and possession', which he associates with Nora's lieux de memoire, a concept he in turn calls out 'as clear and unreflective an indication of the link between the ideology of possessive individualism and the ownership of the national patrimoine as one could ever find in scholarly writing ${ }^{\prime}{ }^{3}$ In a similar vein, Alexander Etkind, recalling Walter Benjamin's insight that 'memory is not an instrument for exploring the past but its theatre', suggests:

materializing memory in the public sphere often entails fiction rather than truth, allegories rather than facts, an irony rather than tragedy. These allegoric images both retain their dependency on the past and affirm the present's striking difference from it. Mimicking the past, they also assert that the past has passed... these allegoric images work as mnemonic tools that revive the past and, simultaneously, as artistic devices that celebrate its death."

Conservation in situ enlists these archaeological remains in public memory work that is both allegorical and rhetorical, and the "up close and personal' experience of the material past that they provide intensifies the experience of authenticity, perceived through the deep history of ruins and the sensuous qualities of the patina of age. In understanding heritage as a material structure for the 'accumulation of affect', I argue that the affective qualities of ruins and archaeological traces, and of how people feel heritage and the past through aesthetic and sensuous experiences of materiality, authenticity, locality and identity, bring us closer to understanding how heritage works. 


\section{ACKNOWLEDGEMENTS}

Thanks to William Moss for his extraordinarily generous guidance through Quebec heritage and archaeology and also to Louise Pothier at Pointe-à-Callière. Thanks to Jane Lydon as always for stimulating collaboration and mentorship, and all the other contributors to this volume for our adventure in snowy Quebec in January 2014! Finally, thanks to Paul Ashton for his patience and gentle stewardship of this volume.

\section{ENDNOTES}

See for example Tracy Ireland, 'The ethics of visibility: archaeology, heritage and memories of settler colonialism', in Tracy Ireland and John Schofield (eds), The ethics of cultural heritage, Springer, New York, 2015, pp105-125; Gillian Rose and Divya P. Tolia-Kelly, 'Visuality/Materiality: Introducing a Manifesto for Practice', in Gillian Rose and Divya P. Tolia-Kelly (eds), Visuality/Materiality: Images, Objects and Practices, Ashgate, Surrey, 2012, pp1-12.

'Sara Ahmed, 'Affective Economies', Social Text, vol 22, no 2, 2004, pp117-139.

${ }^{3}$ The Big Dig Archaeological Site (Online), 2016. Available at: http: / / thebigdig.com.au/thebigdig/site/ (accessed 20 November 2016).

4 Godden Mackay Heritage Consultants and Grace Karskens, The Cumberland/Gloucester Streets Site, The Rocks, Archaeological Investigation Report, Godden Mackay Logan, Sydney, 1999; Grace Karskens, Inside the Rocks: The Archaeology of a Neighbourhood, Hale and Iremonger, Sydney, 1999.

s Tracy Ireland, 'Grounding Identity: exploring perceptions of urban archaeological sites in Australia and New Zealand', Historic Environment, vol 24, no 3, 2012, pp1927.

'Sian Jones, 'Negotiating Authentic Objects and Authentic Selves: Beyond the Deconstruction of Authenticity', Journal of Material Culture, vol 15, no 2, 2010, pp181-203.

Cornelius Holtorf, ‘On Pastness: A reconsideration of materiality in archaeological object authenticity' Anthropological Quarterly, 86 (2) 2013, pp427-433.

${ }^{8}$ For a summary of this literature see Emma Hutchinson, Affective Communities in World Politics, Cambridge University Press, 2016, p102ff

- Sara Ahmed op cit p119.

${ }^{10}$ ibid p121.

"ibid p121.

"See Sian Jones op cit p189, where she discusses Ruskin's concept of 'voicefulness' as connected to concepts of authenticity in heritage; Holtorf, op cit.

${ }^{13}$ Kevin Hetherington, 'The Ruin Revisited' in Gillian Pye and Simone Schroth (eds) Trash Culture: Objects and Obsolescence in Cultural Perspective, Peter Lang, Oxford, New York, 2010, pp27-49.

"Sara Ahmed, The Cultural Politics of Emotion, Edinburgh University Press, Edinburgh, 2004, p196

${ }^{15}$ Hetherington, op cit; Andreas Huyssen, 2010, 'Authentic Ruins: Products of Modernity' in Julia Hell and Andreas Schonle (eds) Ruins of Modernity, Duke University Press, Durham and London, 2010 pp17-28.

${ }^{16}$ Anne Laura Stoler, 'Imperial Debris: Reflections on Ruins and Ruination', Cultural Anthropology 23 (2), 2008, p194

"Bruce G. Trigger, A History of Archaeological Thought. Cambridge University Press, Cambridge, 1989.

${ }^{18}$ Yannis Hamilakis, The Nation and its Ruins, Oxford University Press, Oxford, 2007, p.295

19 Richard Handler, 'Authenticity', Anthropology Today 2, (1), 1986, pp.2-4.

${ }^{20}$ Richard Handler, Nationalism and the Politics of Culture in Quebec, University of Wisconsin Press, Madison, 1988. 
${ }^{2}$ ibid; and see Gilles Lauzon and Madeleine Forget, Old Montreal History through Heritage, Les Publications du Quebec, Sainte-Foy Quebec, 2004, p277.

"Marc Boudreau (ed) Pointe-à-Callière, Experience the Past, Montreal Museum of Archaeology and History, Montreal, 1992

${ }_{23}$ Pierre Desrosiers, L'archéomuséologie: La recherche archéologique entre au musée, Presses de l'Université Laval, Quebec, Canada, 2011, p67.

${ }^{24}$ ibid, p67.

${ }_{25}$ Pierre Nora, 'Between Memory and History: Les Lieux de Mémoire', Representations Special Issue: Memory and Counter Memory, vol 26, 1989, pp7-24.

${ }_{26}$ Desrosiers, op cit, pp70; 73.

${ }^{2}$ ibid, p134.

${ }_{28}$ Shannon Lee Dawdy, 'Profane archaeology and the existential dialectics of the city', Journal of Social Archaeology, vol 16, no 1, 2015, p33.

${ }^{29}$ Michael Herzfeld, 'Whatever happened to 'influence'?: The anxieties of memory', Archaeological Dialogues, vol 10, no 2, 2004, pp91-203.

${ }^{30}$ Laurent Olivier, The dark abyss of time: Archaeology and Memory, translated by Arthur Greenspan, Altamira Press, Lanham, 2011.

${ }^{31}$ Dawdy, op cit. p33.

${ }^{22}$ Jane Bennett, Vibrant Matter: A political ecology of things, Duke University Press, Durham, 2010.

${ }^{3}$ Régis Debray, Transmettre, Editions Odile Jacob, Paris, 1997, p110 cited in Desrosiers, op cit, p98.

${ }^{3}$ Carole Blair, Greg Dickinson and Brian L. Ott, Introduction:

Rhetoric/Memory/Place', in Greg Dickinson, Carole Blair and Brian L. Ott (eds), Places of Public Memory The Rhetoric of Museums and Memorials, The University of Alabama Press, Tuscaloosa, 2010, pp1- 54.

${ }^{35}$ Ruth M. van Dyke and Susan Alcock, 'Archaeologies of Memory: an introduction', in Ruth M. van Dyke and Susan Alcock (eds), Archaeologies of Memory, Blackwell, Oxford, 2003, pp1-14; p 6

${ }^{36}$ Herzfeld, op cit.

${ }^{37}$ Herzfeld, op cit, citing Handler 1988, op cit, p198.

${ }^{38}$ Alexander Etkind, Warped Mourning: Stories of the Undead in the land of the Unburied, Stanford University Press, Stanford California, 2013, p109. 